\title{
Agri-Environmental Indicators: a Systemic Review to Assess New EU Green Deal Policies
}

\author{
Salvan M. ${ }^{1}$, Bertoni D. ${ }^{1}$, Cavicchioli D. ${ }^{1}$, Bocchi S. ${ }^{1}$
}

${ }_{1}$ Department of Environmental Science and Policy

University of Milan, via Celoria 2, 20133, Milan, Lombardy, Italy

\begin{abstract}
Every intervention of planning, implementation, and monitoring of agricultural and agri-environmental policies requires assessment tools that should have the characteristics of relevance, completeness, interpretability, data quality, efficiency, and overlapping. Despite the extensive selection of bibliographies and numerous projects designed to develop agri-environmental indicators necessary for assessing the sustainability of new policies, it is difficult to have an integrated and updated set of indicators available, which can be an effective and practical application tool to assists policymakers, researchers, and actors in policy design, monitoring and impact assessment. Particularly, such need is pressing to face the new environmental challenges imposed by the upcoming European Union Green Deal on the Common Agricultural Policy (CAP) post 2023.

This study, therefore, aims to fill this gap by proposing a selection methodology and different pools of agrienvironmental indicators differentiated based on a scale approach (crop-farm-district-region). Furthermore, we have attempted to validate our approach by quantifying selected indicators for a specific evaluation necessity, represented in this case by an assessment of environmental impact of land use change induced by CAP greening requirements in the Northern Italy context. Results of this validation show original crops' impacts comparison, but also highlight great knowledge gaps in the available literature.

Keywords: Policy Assessment, Green Deal, EU Common Agricultural Policy, Scaled Indicators, Greening
\end{abstract}

\section{Introduction}

1 
Over the last decades, the Common Agricultural Policy (CAP) has moved towards the integration of environmental sustainability goals. This process has led in time to several innovations in the toolset of such policy. Introduction of first agri-environmental measures in 1992, decoupling of direct payments and their conditionality to environmental cross-compliance, after 2003 Fischler Reform, and, more recently, implementation of the greening payment in 2015 represent the most striking examples of how the CAP has been directed toward the inclusion of environmental issues. However, despite many 'green tools', put in place by the recent CAP reforms, the debate around the genuineness of environmental policy integration into the CAP is very lively. Many authors claim that behind the ongoing process of CAP greening lies an attempt to justify the large budgetary allocation of this policy toward a more and more environmentally concerned public opinion, but actually confirming the usual productivist paradigm through the back door [1]. Some authors even go so far as to speak of 'greenwashing' in reference to this process [2]. Doubts also arise regarding the real effectiveness of specific CAP green instruments. For instance, voluntary agri-environmental measures could be affected by adverse selection bias, leading to overcompensation of beneficiaries and limited additional environmental effects $[3,4,5]$. Environmental potentiality of the recent greening direct payment was also widely debated $[6,7,8,9,10,11]$.

Questions and uncertainties about the real effectiveness of the CAP instruments from an environmental perspective claim for a rigorous evaluation process. This is most needed especially at this stage, in the imminence of the new ambitious CAP programming period after 2023, enhancing for greater flexibility and more tailored solutions for farmers' support, but also demanding for policy performances' measurement. Moreover, the new EU Climate Action and European Green Deal will align in a common framework all EU policies concerned with climate and environment, including CAP post 2023, according to a stronger resultsbased approach. In fact, the Farm to Fork Strategy, that is the agricultural dimension of the European Green Deal, sets precise quantitative environmental targets related to soil and water pollution, GHG emissions from farming activities, and rural biodiversity to which the future CAP must contribute $[12,13,14,15,16]$. 
As a consequence, future agricultural and agro-climatic-environmental policy interventions will need more effective indicators' toolsets for an efficient monitoring and assessment, crossing already known evaluation frameworks $[14,16,17,18,19,20,21,22,23,24]$.

However, current CAP assessment remains at stake, being based on a limited scale approach, and poorly connected to future climatic challenges $[25,26,27,28,29,30]$. With reference to the first issue, scale approach means starting from a small context analysis, as field-crop system, and progressively enlarging the perspective to wider levels, like farm, district and regional ones, as commonly applied on territorial studies and planning $[31,32,33,34]$. Scale-approach is crucial to: i) enhance quantitative data' information content and integrate different data sources; ii) analyse specific governance and policy interactions and dose-response; iii) connect agri-environmental indicators to their most suitable dimension, overcoming background-related bias.

Agri-environmental indicators can be useful tools to assess and monitoring agrosystems' "health state" and related changes induced by policy measures. These indicators should be designed for a quick ex-ante and expost evaluation of the environmental effects of agricultural policies in the EU members' regions. Such kind of policy monitoring requires indicators having, at the same time, enough territorial coverage (not exclusively sitespecific) and a certain degree of disaggregation. Commonly available agri-environmental indicators are usually unfit for effective policy monitoring, being sometimes customized for a single research site, or conversely they are "aggregated" and not functional in terms of data requirements and univocal use $[1,2,35,36,37,38,39,40,41,42,42,43,44,45]$. Moreover context-specific approaches are functional on monitoring and result checking perspective for single case studies analysis, but they are less useful in terms of policy planning and implementation at a wider territorial level [28,46,47,48,49,50,51].

The scale approach is different from the currently in place context-specific approach, because it is not linked to a specific farm specialization and/or to particular specific CAP measures $[18,52,53,54,55,56]$. In this respect, our research shows a focused scale approach that can be implemented at different levels: crop, farm, district, and region [57,58,59]. 
Furthermore, we included a quantitative aspect in indicators' selection, as traditional EU CAP environmental assessment is mainly based on qualitative indicators and is lacking of a broad quantitative evaluation framework; this common lack of quantitative data implies serious constraints to future Green Deal result-based policies $[3,33,44,46,47,60,61,62,63]$.

Quantitative and scale approach are indissolubly connected: quantitative impacts assessment is poorly relevant if it is not scaled up to more vast areas compared to context-specific studies, and at the same time it is quite hard to estimate real crop or supply chain environmental impacts if quantitative surveys are just dispersed in several small case studies, not being progressively scaled-up along different territorial levels (crop-field, farm, district, region).

A qualitative-quantitative and scale-crop-ecosystem integrated approach can be even more easily connected with the landscape and territorial approach $[28,31,34,64,65]$. In this regard, for instance, Life Cycle Approach offers a coherent perspective with its typical own indicators, being focused on a mass input-output approach, offering an important hint to introduce a new crop approach and environmental evaluation $[66,67,68,69,70,71,72,73,74,75,76,77]$.

To resume future indicators' set must be a relatively simple tool with particular regard to an integrated approach linking agricultural activities impacts with overall ecosystemic conditions. For indicators, selection should be advisable, compact, univocal, comprehensive, and not excessively context-specific.

Given these requirements, in our study we selected a pool of integrated and multi-scaled agri-environmental indicators to evaluate the environmental impact of CAP instruments on a wide range. Selection process was carried out screening in the available and well-accepted scientific literature studies concerning environmental indicators and integrating them in a coherent unique pool. Such pool was organized in sub-items and crop-scale subsections, suitable for a wide-range impact assessment. 
Lastly, we looked for a validation of our approach by quantifying selected indicators for a specific policy evaluation need, represented in this case by the assessment of agro-ecological impact of land use change induced by CAP greening requirements in the Northern Italy context.

Against this background, the aim of this paper is threefold: i) to analyse the current state of the art for selecting a set of agri-environmental indicators useful for bridging the gap in current policies assessment; ii) to provide the stakeholders (policymakers, researchers, etc) for a new comprehensive and harmonised set of indicators, currently not available, for ex-ante and ex-post assessment of CAP instruments, and for a better design of future policy tools; and iii) to validate our set of indicators by attempting to provide their quantification for a specific evaluation need at crop scale level.

\section{Materials and Methods}

We conducted an extensive bibliographical research on available and recent agri-environmental indicators' pools referred to the EU farming contexts, into public available academic databases $(\mathrm{CAB}$, Web of Science, and Scopus have been widely explored and used). During the indicators' selection process we considered agricultural pollution sources and available indicators to detect them. In particular we focus on quantitative mass-based agri-environmental indicators. "CAP policy assessment", "agri-environmental indicators", "agrifood system assessment", "scaled assessment" were used as keywords during the database research. A major focus was posed on multi-disciplinary environmental impact evaluations, in particular considering direct and related agricultural activities impacts. Unity of measure was relevant. Unities of measures referred to mass, and not to crop area, can help to provide a more effective environmental impact calculation, as they are more "neutral" and they provide a more direct data comparison.

Among all available agri-environmental indicators' datasets we also initially considered:

- Standard Eurostat indicators: we included them because they are easy to be detected and they are georeferenced, even if at a large scale. However, they are not always updated, functional for deep analysis, being usually related to the large-scale pollution impact on farmland, water and air [12]; 
- FAO - Sustainable Assessment on Food and Agriculture Systems (SAFA) indicators: these series miss important issues, not expliciting clear connections among different indicators' pools, and being macroaggregated and poorly functional, so we put them apart [44];

- Context specific environmental impact assessment papers, which can offer regionally circumscribed impacts' estimation.

During the process of selection of the indicators, we followed the following criteria:

- Relevance: to describe logically, and scientifically, a direct impact on the farm's sustainability;

- Comprehensiveness: to be relevant to all systems combining food and non-food production;

- Interpretability: indicators must be easily interpretable for different scale indicators;

- Data Quality: to be relevant in describing the considered phenomena;

- Efficiency: indicators must be quick and easy to collect;

- Overlap: to avoid redundancies with other indicators already selected for the pool.

Therefore we developed an integrated pool of indicators based on the territorial and functional scale of the agricultural activities. This set is meant to be different from current CAP evaluation indicators: i) transversal in the matter of farm specialization; ii) complex and wide in terms of agro-systems characteristics, iii) easy to be used by policymakers and to be understood by stakeholders.

All described indicators have been presented in Annex I.

In particular we considered the following agri-environmental indicators:

- Climate Change (CC, expressed as kg CO 2 eq/ha)

- Climate Change (CC, expressed as kg CO 2 eq/Mg)

- Particulate Matter Formation (PM, expressed as kg PM2.5 eq/Mg) 
- Pesticide and herbicide use (kgไha)

- Human Toxicity (kg 1,4-DB eq/Mg DM)

- Photochemical Ozone Formation (POF, expressed as kg NMVOC eq./Mg DM)

- Terrestrial ecotoxicity (1.4-dichlorobenzene equivalents $\mathrm{kg} / \mathrm{Mg}$ )

- Acidification (kg SO 2 equivalents/Mg)

- Eutrophication (kg PO 4 equivalents/Mg)

In order to provide a validation for our procedure, we decided to apply it to a concrete evaluation need. In particular, starting from the selected pool, we tried to quantify indicators, detailed at crop scale, which could be useful for an ex-post assessment of the 2015-2020 CAP greening payment effects. CAP greening payments provided financial incentives for farmers diversifying arable crops and devoting part of farming land to ecological focus areas (see EU Regulation n. 1307/2013). As the greening scheme was implied in promoting land use change and crops substitution, in such a particular case the crop scale indicators are deemed to be the most appropriate ones for a feasible, but at the same time reliable, evaluation of related environmental effects. As Northern Italy was one of the EU regions where greening has had the greatest impact in terms of land use change (as esteemed by [5,78,81], we preferably extracted values referred to this geographical context. In particular, we considered the main cultivated crops and farmland uses, in that area, as maize, green maize, wheat, ryegrass, sorghum, triticale, rye, barley, rice, tomato, rapeseed, sunflower, alfalfa, permanent grassland, horticulture crops, and poplar. For each combination of indicator and crop, we have attempted, where possible, to find a quantification useful for a hypothetic impact assessment process (see Annex II). Not all indicator-crop combinations were covered due to lack of detailed data. In few cases we found the same quantification by two different studies $[66,67,68,69,70,71,72,73,74,75,76,77]$.

\section{Results and Discussion}

The presented indicators' pools can be useful in a perspective of territorial, wide-range analysis, especially focused on crops specific farming impacts. According to traditionally available studies concerning 
environmental assessment, we observed two different scale approaches often applied: environmentally and naturally focused studies, usually concentrated on a farm scale, and wider scale studies mainly devoted to an agronomic analysis of applied policies. This paper can provide an "ice-breaking solution" with this new framework out of previous papers' "conceptual boxes", being the first example of agri-environmental assessment applied at different scales, integrating biodiversity and emission and pollution indicators. Combining indicators from different datasets is challenging, but this approach merges relevance and comprehensiveness of different environmental impacts, being all major agri-environmental impacts united in a unique pool. Some possible weaknesses and criticisms emerge: i) The lack and disproportion of available data at different scale levels. Farm-level is easily representable, mainly with site-specific studies, which are usually crop-related, underestimating ecosystem-wide matrix impacts (e.g. biodiversity). In any case they are precious as the first source of data and direct crops' impacts. The regional level is represented by national or regional databases. Regional scaled indicators are not designed to be lowered into local contexts, while they are useful only for general overviews, being mainly linked to a broader statistical perspective. District level is a middleground between the other scale levels, being an intermediate body between farm and regions. Usually it is referred to a farm specialization. This level is crucial, but missing in statistical surveys on environmental impacts assessment. ii) Data representativeness. Crops' environmental impacts are mainly represented in casespecific academic papers, difficult to be scaled up. On the contrary, they are rather missing in public regional statistics, where they would have more potential in terms of general impact assessment. The stronger focus is posed on arable crops and cereals, while other productions tend to be neglected and not represented at the same scale. iii) Partial overlapping. Excessively generic agri-environmental indicators, tend not to be properly focused to represent contiguous, but distinct, phenomena. It may be observed how some indicators show greater interest and coverage (e.g. Climate Change and $\mathrm{CO}_{2}$ eq emissions), but huge data gaps limit assessments for some impacts' assessments (e.g. Eutrophication, Acidification, Particular Matter Formation, Pesticides and Herbicides use, etc). Previous considerations found confirmation in our case study referred to the estimation of 
environmental effects due to the implementation of CAP greening crop diversification in the Northern Italy context. We obtained many crop-related environmental impacts, that could integrate farmland use change estimation models, such as those implemented in that area by [78,79,80,81]. In fact, assigning to each crop its related environmental parameter, we would be able to derive an estimation of policy environmental impact starting from the estimated changes in crop allocation. We found crop related environmental impact on the most relevant crops in the studied area. Data show internal coherence, as they converge on a common order size, especially where referred to similar crops.

However, we also observed some limits and data gaps, referred to many combination of crops and agrienvironmental indicators. In particular, we should assess the following constraints:

1) Total lack of data for some categories of farmland uses, such as fallow land, particular types of grassland, landscape features, agro-forestry systems, cover crops, and some industrial crops;

2) Data deficiency for many categories of indicators, including Particulate Matter Formation, Pesticides and Herbicides, Human Toxicity, Photochemical Ozone Formation, and Eutrophication. From this perspective, just main sources of pollution can be quantitatively estimated, even if on a very narrowed base and in a specific context, so great sources of pollution remain not assessed and estimated.

Our approach shows all constraints to develop an integrated future CAP's evaluation. Lacking of data combined with datasets separation prevent from a developing integrated evaluation approach. Future data research will need to be more impact-focused and exploring, mapping in details and improving quality different data sources. Clarify data connection can also be a future aim in current research's context.

\section{Conclusions}

We tried to develop an integrated pool of indicators, suitable for environmental evaluation for the farming sector along with different scale steps and suitable for different commonly grown in EU crops. The final expected result was supposed to be a coherent framework, including data coming from different sources and 
data banks. Until the present day agri-environmental indicators for environmental impacts assessment have been just partially available in the European context; in particular we noticed a common gap in clearly pairing environmental indicators to spatial-context scale at different levels.

The main need consists of a selected and narrowed pool, functional for the CAP environmental impacts monitoring and assessment. The selection process was carried out in order to set up an advisable compact, univocal, comprehensive, and not excessively particular pool. Bridging policy and agro-ecosytems analysis is increasingly actual, given the emphasis on environmental goals by the new EU Green Deal strategy. In this sense, our paper constitutes a partial contribution to the ambitious objective of a comprehensive assessment and evaluation of CAP environmental and climate impacts.

Agri-environmental indicators from different databases have been integrated in a unique pool and divided into suitable sub-sections. Unity of measure was a critical point, and working on standardized mass-based unity of measure has been a practical solution to integrate different datasets.

Among the main constraints of current research, we can include: i) it is an alternative sight on the issue of environmental impacts' assessment; ii) lack of validation on the field with diversified case studies, which is linked to the issue of having a complete and coherent bibliography; iii) limited crop-related information availability.

In conclusion, the current paper is intended to be the first proposal for a new series of environmental indicators studies, based on a scale approach. Extending crops and indicators pools should be a purpose for future and more detailed researches, including for instance a more explicit and wider integration between LCA's and Eurostat's indicators pool.

\section{Acknowledgments and Funding}

This study has been supported by Fondazione Cariplo, within the research project "Evaluation of CAP 20152020 and taking action - CAPTION" (Project Id: 2019-3582). 
6. Conflicts of Interest: The authors declare no conflicts of interest.

\section{References}

1. Erjavec, K., \& Erjavec, E. . 'Greening the CAP'-Just a fashionable justification? A discourse analysis of the 2014-2020 CAP reform documents. Food Policy 2015, 51, 53-62.

2. Alons, G. . Environmental policy integration in the EU's common agricultural policy: greening or greenwashing?. Journal of European Public Policy 2017, 24 (11), 16041622. DOI: $10.1080 / 13501763 . .1334085$

3. Uthes, S., Matzdorf, B. . Studies on agri-environmental measures: a survey of the literature. Environmental management, 2013, 51(1), 251-266. DOI 10.1007/s00267-012-9959-6

4. Chabé-Ferret, S., Subervie, J. . How much green for the buck? Estimating additional and windfall effects of French agro-environmental schemes by DID-matching. Journal of Environmental Economics and Management 2013, 65(1), 12-27. DOI: 10.1016/j.jeem.2012.09.003

5. Bertoni, D., Curzi, D., Aletti, G., \& Olper, A. . Estimating the effects of agri-environmental measures using difference-in-difference coarsened exact matching. Food Policy 2020, 90, 1017. DOI: 10.1016/j.envsci.2021.01.008

6. Hart, K., Baldock, D. . Greening the CAP: Delivering environmental outcomes through pillar one. Institute for European Environmental Policy 2011, 1(11), 1-26.

7. Matthews, A. . Greening agricultural payments in the EU's Common Agricultural Policy. Bio-based and Applied Economics 2013, 2(1), 1-27. ISSN 2280-6180 (print) (C Firenze University Press ISSN 2280-6172 (online) 
8. Matthews, A. . Greening the CAP: a missed opportunity. Institute of International and European Affairs. 2013 (Available at: https://docs.google.com/viewerng/viewer?url=https://www.iiea.com/wpcontent/uploads/free-downloads-files/temp-files/00505878500.pdf)

9. Westhoek, H. J., Overmars, K. P., Van Zeijts, H. . The provision of public goods by agriculture: Critical questions for effective and efficient policy making. Environmental Science \& Policy, 2013, 32, 5-13. https://doi.org/10.1016/j.envsci.2012.06.015

10. Hauck, J., Schleyer, C., Winkler, K.J., Maes, J. . Shades of Greening: Reviewing the Impact of the new EU Agricultural Policy on Ecosystem Services. Change Adaptation Socioecol. Syst. 2014, 1, 51-62.

11. Lazíková, J., Bandlerová, A., Rumanovská, L., Takáč, I., Lazíková, Z. . Crop Diversity and Common Agricultural Policy. The Case of Slovakia. Sustainability 2019, 11, 1416. doi:10.3390/su11051416

12. Eurostat https://ec.europe.eu/eurostat/web/agriculture/agri-environmental-indicator (10/9/2020)

13. Matthews, A. (2020). The new CAP must be linked more closely to the UN Sustainable Development Goals. Agricultural and Food Economics 2020, 8, 19. https://doi.org/10.1186/s40100-020-00163-3

14. Biffi, S., Traldi, R., Crezee, B., Beckmann, M., Egli, L., Schmidt, D.E., Motzer, N., Okumah, M., Seppelt, R., Slabbert, E.L., Tiedeman, K., Wang, H., Ziv, G. . Aligning agri-environmental subsidies and environmental needs: a comparative analysis between the US and EU. Environ. Res. Lett. 2021, 16054067. https://doi.org/10.1088/1748-9326/abfa4e

15. Herman, K.S., Shenk, J. . Pattern Discovery for climate and environmental policy indicators. Environmental Science and Policy 2021, 120, 89-98. https://doi.org/10.1016/j.envsci.2021.02.003

16. Montanarella, L., Panagos, P. . The relevance of sustainable soil management within the European Green Deal. Land Use Policy 2021, 100, 104950. https://doi.org/10.1016/j.landusepol.2020.104950 
17. Gravey, V. . Finally Free to Green Agriculture Policy? UKpost-Brexit Policy Developments in the Shadowof the CAP and Devolution. EuroChoices 2019, 18(2). DOI: 10.1111/1746-692X.12234

18. Dupraz, P., Guyomard, H. . Environnement et climat dans la Politique Agricole Commune. EuroChoices 2019, Vol.18(1), p.18. DOI: 10.1111/1746-692X.12219

19. European Commission. Analysis of links between CAP Reform and Green Deal. Brussels, 2020 SWD(2020) 93 final

20. Eu Commission. A Farm to Fork Strategy for a fair, healthy and environmentally-friendly food system 2020, $\operatorname{COM}(2020) 381$ final .

21. Dabkiene, V., Balezentis, T., Streimikiene, D. . Development of agri-environmental footprint indicator using the FADN data: Tracking development of sustainable agriculturaldevelopment in Eastern Europe. Sustainable Production and Consumption 2021, 27 2121-2133. DOI: 10.1016/j.spc..05.017

22. Giuseppe Gargano, Francesco Licciardo, Milena Verrascina and Barbara Zanetti. The Agroecological Approach as a Model for Multifunctional Agriculture and Farming towards the European Green Deal 2030Some Evidence from the Italian Experience. Sustainability 2021, 13, 2215. https://doi.org/10.3390/su13042215

23. Rapsikevicius, J., Bruneckiene, J., Lukauskas, M., Mikalonis, S. . The Impact of Economic Freedom on Economic and Environmental Performance: Evidence from European Countries. Sustainability 2021, 13, 2380. https://doi.org/10.3390/su13042380

24. Wolf, S., Teitge, J., Mielke, J., Schütze, F., Jaeger, C. . The European Green Deal - More Than Climate Neutrality. International Economics, 2021, 2, ZBW - Leibniz Information Centre for Economics. DOI: 10.1007/s10272-021-0963-Z 
25. Singh, M., Marchis, A., Capri, E. . Greening, new frontiers for research and employment in the agrofood sector. Science of the Total Environment 2014, 472 , 437-443. https://doi.org/10.1016/j.scitotenv.2013.11.078

26. Jordbruks Verket. The greening of CAP in practice - Costs versus Environmental Benefits. Editor Torben Södeberg, 2016.

27. Bouma J. and J.H.M. Wösten . How to characterize 'good' and 'greening' in the EU Common Agricultural Policy (CAP): the case of clay soils in the Netherlands. Soil Use and Management, December 2016, 32, 546-552. DOI: 10.1111/sum.12289

28. Gocht, A., Pavel Ciaian, P., Bielza, M., Terres, J.M, Roder, N., Himics, M.,Salputra, G. . EU-wide Economic and Environmental Impacts of CAP Greening with High Spatial and Farm-type Detail. Journal of Agricultural Economics 2017, Vol. 68, No. 3, 651-681. doi: 10.1111/1477-9552.12217

29. Pe'Er, G., Zinngrebe, Y., Moreira, F., Sirami, C., Schindler, S., Müller, R., Lakner, S. . A greener path for the EU Common Agricultural Policy. Science 2017, 365(6452), 449-451. DOI: 10.1126/science.aax3146

30. Henderson B., Lankoski, J. . Assessing the Environmental Impacts of Agricultural Policies. Applied Economic Perspectives and Policy 2020, volume 00, number 00, pp. 1-16. doi:10.1002/aepp.13081

31. Stein A., Riley J., Halberg N. . Issues of scale for environmental indicators. Agriculture, Ecosystems and Environment 2001, 87, 215-232 PII: S 0167 - 8809 ( 01 ) $00280-8$

32. Bailey, D., Herzog, F., Augenstein, I., Aviron, S., Billeter, R., Szerencsits, E., Baudry, J. . Thematic resolution matters: Indicators of landscape pattern for European agro-ecosystems. Ecological Indicators 2007, 7, 692-709. doi:10.1016/j.ecolind.2006.08.001 
33. Fry, G., Tveit, M.S., Ode, A., Velarde, M.D. . The ecology of visual landscapes: exploring the conceptual common ground of visual and ecological landscape indicators. Ecological Indicators 2009, 9, 933947. Doi:10.1016/j.ecolind.2008.11.008

34. Derunova, E., Andryushenko, S., Gerchikova, E., Firsova, A., Derunov, V. . Monitoring of Innovative Activities Effectiveness in Agriculture. Scientific Papers Series Management, Economic Engineering in Agriculture and Rural Development 2019, Vol. 18, Issue 3, PRINT ISSN 284-7995, E-ISSN 2285-3952.

35. Primdahl, J., Peco, B., Schramek, J., Andersen, E., Oñate, J.J. . Environmental effects of agrienvironmental schemes in Western Europe. Journal of Environmental Management 2003, 67, 129-138. https://doi.org/10.1016/S0301-4797(02)00192-5

36. Delbaere, B., A. Nieto Serradilla (Eds) . Environmental risks from agriculture in Europe: Locating environmental risk zones in Europe using agri-environmental indicators. 2004, Tilburg, ECNC-European Centre for Nature Conservation

37. Venturelli, R.C. Galli, A. . Integrated indicators in environmental planning: Methodological considerations and applications. Ecological Indicators 2006, 6, 228-237 doi:10.1016/j.ecolind.2005.08.023

38. Bockstaller, C., Guichard, L., Makowski, D., Aveline, A., Girardin, P., Plantureux, S. . Agrienvironmental indicators to assess cropping and farming systems. A review. Agron. Sustain. Dev. 2008, 28 , 139-149 c INRA, EDP Sciences. DOI: 10.1051/agro:2007052

39. Salvati, L., Zitti, M. . The Environmental "Risky" Region: Identifying Land Degradation Processes Through Integration of Socio-Economic and Ecological Indicators in a Multivariate Regionalization Model. Environmental Management 2009, 44:888-898. DOI 10.1007/s00267-009-9378-5

40. Giling, D.P., Cesarz, S., Beaumelle, L., Guerra, C., Thakur, M.P., Eisenhauer, N., Hines, J., Phillips, H.R.P., Ferlian, O., Gottschall, F., Sendek, A., Siebert, J., Barnes, A.D. . A niche for ecosystem multifunctionality in global change research. Glob Change Biol. 2019, 25:763-774. DOI: 10.1111/gcb.1452 
41. Redlich S., Martin, E.A., Wende, B., Dewenter, S. . Landscape heterogeneity rather than crop diversity mediates bird diversity in agricultural landscapes. PLoS ONE 2018, 13(8). https://doi.org/10.1371/journal.pone.0200438

42. Schaller, L., Targetti, S., Anastasio J. Villanueva, Zasada, I., Kantelhardt, J., Arriaza, M., Bal, T., Bossi Fedrigotti, V., Handan Giray, F., Häfner, K., Majewski, E., Malak-Rawlikowska, A., Dimitre Nikolov, Paoli, J.C., Piorr, A., Rodríguez-Entrena, M., Ungaro, F., Verburg, P.H., Van Zanten, B., Viaggi, D. . Agricultural landscapes, ecosystem services and regional competitiveness-Assessing drivers and mechanisms in nine European case study areas. Land Use Policy 2018, 76, 735-745. https://doi.org/10.1016/j.landusepol.2018.03.001

43. Vallecillo, S., La Notte, A., Ferrini, S., Maes, J. . How ecosystem services are changing: an accounting application at the EU level. Ecosystem Services 2019, 40, 101044. https://doi.org/10.1016/j.ecoser.2019.101044

44. Iocola, I., Angevin, F., Bockstaller, C., Catarino, R., Curran, M., Messéan, A., Schader, C., Stilmant, D., Van Stappen, F., Vanhove, P., Ahnemann, H., Berthomier, J., Colombo, L., Dara Guccione, G., Mérot, E., Palumbo, M., Virzì, N., Canali, S. . An Actor-Oriented Multi-Criteria Assessment Framework to Support a Transition towards Sustainable Agricultural Systems Based on Crop Diversification. Sustainability 2020, 12, 5434. doi:10.3390/su12135434

45. Zingg, S., Ritschard, E., Arlettaz, R., Humbert, J-Y. . Increasing the proportion and quality of land under agri-environment schemes promotes birds and butterflies at the landscape scale. Biological Conservation 2019, 231, 39-48. https://doi.org/10.1016/j.biocon.2018.12.022

46. Migliorini, P., Vazzana, C. . Biodiversity Indicators for Sustainability Evaluation of Conventional and Organic Agro-ecosystems. Ital. J. Agron. / Riv. Agron. 2007 2:105-110. https://doi.org/10.4081/ija.2007.105 
47. Migliorini, P., Galioto, F., Chiorri, M., Vazzana, C. . An integrated sustainability score based on agroecological and socioeconomic indicators. A case study of stockless organic farming in Italy. Agroecology and Sustainable Food Systems. 2018, DOI: 10.1080/21683565.2018.1432516

48. Bassanino, M., Sacco, D., Zavattaro, L., Grignani, C. (2011). Nutrient balance as a sustainability indicator of different agro-environments in Italy. Ecological Indicators 2011, 11, 715-723. doi:10.1016/j.ecolind.2010.05.005

49. Andersen, E. . The farming system component of European agricultural landscapes. Europ. J. Agronomy 2017, 82, 282-291. http: //dx.doi.org/10.1016/j.eja.2016.09.011 DOI: 10.1016/j.eja.2016.09.011

50. Weltin, M., Zasada, I., Franke, C., Piorr, A., Raggi, M., Viaggi, D. . Analysing behavioural differences of farm households: An example of income diversification strategies based on European farm survey data. Land Use Policy 2017, 62, 172-184 http://dx.doi.org/10.1016/j.landusepol. 2016.11.041

51. Nilsson, L., Clough, Y., Smith, H.G., Alkan Olsson, J., Brady, M.V., Hristov, J., Olsson, P., Skantze, K., Ståhlberg, D., Dänhardt, J. (2019). A suboptimal array of options erodes the value of CAP ecological focus areas. Land Use Policy 2019, 85, 407-418. https://doi.org.10.1016/j.landusepol.2019.04.005

52. Ansell, D., Freudenberger, D., Munro, N., Gibbons, P. . The cost-effectiveness of agri-environment schemes for biodiversity conservation: A quantitative review, Agriculture, Ecosystems \& Environment 2016, Volume 225, Pages 184-191. https://doi.org/10.1016/j.agee.2016.04.008

53. Riley, M. . How does longer term participation in agri-environment schemes [re]shape farmers' environmental dispositions and identities? Land Use Policy 2016, Volume 52, Pages 62-75. https://doi.org/10.1016/j.landusepol.2015.12.010

54. Riley, M., Sangster, H., Smith, H., Chiverrell, R., Boyle, J. . Will farmers work together for conservation? The potential limits of farmers' cooperation in agri-environment measures. Land Use Policy 2018, 70, 635-646. https://doi.org/10.1016/j.landusepol.2017.10.0 
55. Lovec, M., Šumrada, T., Erjavec, E. . New Delivery Model, Old issues. Inter economics 2020, Vol.55 (2), p.112-119

56. Magaudda, S., D’Ascanio, R., Muccitelli, S., Palazzo, A.M. . 'Greening' Green Infrastructure. Good Italian Practices for Enhancing Green Infrastructure through the Common Agricultural Policy. Sustainability 2020, 12, 2301. doi:10.3390/su12062301

57. Caputo, P., Zagarella, F., Cusenza, M.A., Mistretta, M., Cellura, M. . Energy-environmental assessment of the UIA-OpenAgri case study as urban regeneration project through agriculture. Science of the Total Environment 2020, 729, $138819 \quad$ https://doi.org/10.1016/j.scitotenv.2020.138819. DOI: 10.1016/j.scitotenv.2020.138819

58. Perego A., Rocca A., Cattivelli V., Tabaglio V., Fiorini A., Barbieri S., Schillaci C., Chiodini M.E., Brenna S., Acutis M. . Agro-environmental aspects of conservation agriculture compared to conventional systems: A 3-year experience on 20 farms in the Po valley (Northern Italy). Agricultural Systems 2020, 168, 73-87. https://doi.org/10.1016/j.agsy.2018.10.008

59. Paracchini, M.L., Bulgheroni, C., Borreani, G., Tabacco, E., Banterle, A., Bertoni, D., Rossi, G., Parolo, G., Origgi, R., De Paola, C. . A diagnostic system to assess sustainability at a farm level: The SOSTARE model. Agricultural Systems 2015, 133, 35-53. http://dx.doi.org/10.1016/j.agsy.2014.10.004

60. Gobin, A., Jones, R., Kirkby, M., Campling, P., Govers, G., Kosmas, C., Gentile . Indicators for panEuropean assessment and monitoring of soil erosion by water. Environmental Science \& Policy 2004, 7, 25-38 doi:10.1016/j.envsci.2003.09.004

61. Latruffe, L., Dupuy, A., Desjeux, Y. . What would farmers' strategies be in a no-CAP situation? An illustration from two regions in France. Journal of Rural Studies 2013, 32, 10-25. http: //dx.doi.org/10.1016/j.jrurstud.2013.04.003 
62. Moxely, A., White, B. . Result-oriented agri-environmental schemes in Europe: A comment, Land Use Policy 2014, Volume 39, Pages 397-399. https://doi.org/10.1016/j.landusepol.2014.04.008

63. Louhichi, K., Ciaian, P., Espinosa, M., Colen, L., Perni, A., Gomez y Paloma, S. . Does the crop diversification measure impact EU farmers' decisions? An assessment using an Individual Farm Model for CAP Analysis (IFM-CAP). Land Use Policy 2017, 66, 250-264. http://dx.doi.org/10.1016/j.landusepol.2017.04.010

64. Gonthier, D.J., Ennis, K.K., Farinas, S., Hsieh, H-Y., Iverson, A.L., Batáry, P., Rudolphi, J., Tscharntke, T., Cardinal, B. J., Perfecto, I. . Biodiversity conservation in agriculture requires a multi-scale approach. Proc. R. Soc. B 2014, 281: 20141358. http://dx.doi.org/10.1098/rspb.2014.1358

65. Van Zanten, B.T., Verburg, P.H., Espinosa, M., Gomez-y-Paloma, S., Galimberti, G., Kantelhardt, J., Kapfer, M., Lefebvre, M., Manrique, R., Piorr, A., Raggi, M., Schaller, L., Targetti, S., Zasada, I., Viaggi, D. . European agricultural landscapes, common agricultural policy and ecosystem services: a review. Agron. Sustain. Dev. 2014, 34, 309-325. doi: 10.1007/s13593-013-0183-4

66. Mekonnen, M.M. and Hoekstra, A.Y. . The green, blue and grey water footprint of crops and derived crop products. Value of Water Research Report Series 2010, No. 47, UNESCO-IHE, Delft, the Netherlands.

67. Mekonnen, M.M, Hoekstra, A.Y. . The green, blue and grey water footprint of crops and derived crop products. Hydrol. Earth Syst. Sci. 2011, 15, 1577-1600. doi:10.5194/hess-15-1577-2011

68. Bacenetti, J., Fusi, A., Negri, M., Fiala, M. . Impact of cropping system and soil tillage on environmental performance of cereal silage productions. Journal of Cleaner Production 2015, 86, 49-59. DOI: 10.1016/j.anifeedsci..03.005

69. Lehmann, L., Borzecka, M., Żyłowska, K., Pisanelli, A., Russo, G., Ghaley, B.B. . Environmental Impact Assessments of Integrated Food and Non-Food Production Systems in Italy and Denmark. Energies 2020, 13, 849. doi:10.3390/en13040849 
70. Lovarelli, D., Garcia, L.R., Sánchez-Girón, V., Bacenetti, J. . Barley production in Spain and Italy: Environmental comparison between different cultivation practices. Science of the Total Environment 2020, 707, 135982. https://doi.org/10.1016/j.scitotenv.2019.135982

71. Noya, I., Gonzalez-García, S., Bacenetti, J., Arroja, L., Moreira, M.T. (2015). Comparative life cycle assessment of three representative feed cereals production in the Po Valley (Italy) . Journal of Cleaner Production 2015, 99 ) 250-265 . http://dx.doi.org/10.1016/j.jclepro.2015.03.001

72. Naudin, C., van de Werf, H.M.G., Jeuffroy, M.H., Corre-Hellou, G. . Life cycle assessment applied to pea-wheat intercrops: A new method for handling the impacts of co-products. Journal of Cleaner Production 2014, Volume 73, 15 Pages 80-87. https://doi.org/10.1016/j.jclepro.2013.12.029

73. Zucali, M., Bacenetti,J., Tamburini, A., Nonini, L., Sandrucci, A., Bava, L. . Environmental impact assessment of different cropping systems of home-grown feed for milk production. Journal of Cleaner Production 2018,172, 3734-3746. https://doi.org/10.1016/j.jclepro.2017.07.048

74. Forleo, M.B., Palmieri, N., Suardi, A., Coaloa, D., Pari, L. . The eco-efficiency of rapeseed and sunflower cultivation in Italy. Joining environmental and economic assessment. Journal of Cleaner Production 2018, Volume 172, 20, Pages 3138-3153 https://doi.org/10.1016/j.jclepro.2017.11.094

75. Manfredi M., Vignali, G. . Life cycle assessment of a packaged tomato puree: a comparison of environmental impacts produced by different life cycle phases. Journal of Cleaner Production 2014, Volume 73, Pages 275-284 https://doi.org/10.1016/j.jclepro.2013.10.010

76. Payen, S., Basset-Mens, C., Colin, F., Roignant, P. . Inventory of field water flows for agri-food LCA: critical review and recommendations of modelling options. Int J Life Cycle Assess 2018, 23:1331-1350. DOI $10.1007 / \mathrm{s} 11367-017-1353-4$

77. Valiante, D., Sirtori, I., Cossa, S., Corengia, L., Pedretti, M., Cavallaro, L., Vignoli, L., Galvagni, A., Gomarasca, S., Pesce, G.R., Boccardelli, A., Orsi, L., Lovarelli, D., Facchinettii, D., Pessina, D., Bacenetti, J., 20 
Environmental impact of strawberry production in Italy and Switzerland with 2 different cultivation practices. Science of The Total Environment 2019, Volume 664, Pages 249-261 https://doi.org/10.1016/j.scitotenv.2019.02.046

78. Solazzo, R., Pierangeli, F. . How does greening affect farm behaviour? Trade-off between commitments and sanctions in the Northern Italy. Agricultural Systems 2016, $149, \quad 88-98$ http://dx.doi.org/10.1016/j.agsy.2016.07.013

79. Cortignani, R., Severini, S., Dono, G. . Complying with greening practices in the new CAP direct payments An application on Italian specialized arable farms. Land Use Policy 2017, 61, $265-275$. https://dx.doi.org/10.1016/j.landusepol.2016.11.026

80. Cortignani, R., Dono, G. . CAP's environmental policy and land use in arable farms: An impacts assessment of greening practices changes in Italy. Science of the Total Environment 2019, 647, 516-524. https://doi.org/10.1016/j.scitotenv.2018.07.443 DOI: 10.1016/j.scitotenv.2018.07.443

81. Bertoni, D., Aletti, G., Cavicchioli, D., Micheletti, A., \& Pretolani, R. . Estimating the CAP greening effect by machine learning techniques: A big data ex post analysis. Environmental Science \& Policy 2021,119, 44-53. DOI: $10.1016 /$ j.envsci.2021.01.008

\section{Annex}

Annex I: integrated indicators' list divided by scale and typology.

Scale

Agronomical-Operational

DatabaselSource 
- Area under organic farming (Eurostat_sdg_02_40)

- Agriculture: area under management practices potentially supporting biodiversity (EEA_SEBI020)

- Harmonised risk indicator for pesticides (HRI1), by groups of active substances (Eurostat_sdg_02_51, source: $\mathrm{EC})$

- Ammonia emissions from agriculture

(Eurostat_sdg_02_60, source: EEA)

- Ammonia emissions from agriculture - $\%$ of total emissions (Eurostat_tai07, source: EEA)

- Gross nutrient balance on agricultural land by nutrient (Eurostat_sdg_02_50)

- Estimated soil erosion by water - area affected by severe erosion rate (source: JRC) (Eurostat_sdg_15_50)

- Gross nutrient balance in agricultural land

(Eurostat_t2020_rn310)

- Agriculture: nitrogen balance (EEA_SEBI019)

- Soil organic carbon (EEA_LSI005)

- Share of forest area (Eurostat_sdg_15_10)

- Natural areas:

- Ecosystem coverage (EEA_SEBI004)

- Fragmentation of natural and semi-natural areas (EEA_SEBI013)

- Habitats of European interest (EEA_SEBI005)

- Livestock: 
- Livestock density index (Eurostat_tai09)

- Water:

- Crop water demand (EEA_CLIM033)

- Water exploitation index, plus (WEI+)

(Eurostat_sdg_06_60, source: EEA)

- Water productivity (Eurostat_t2020_rd210)

- Water resources: long-term annual average

(Eurostat_ten00001)

- Water Footprint (Mekonnen and Hoekstra, 2011)

- Agri-environmental (LCA\Quantitative environmental evaluation):

- $\operatorname{GWP}(\mathrm{kg} \mathrm{CO} 2$-eq./yr):

-Human
-Livestock
-Tillage
-Fertilizers
-Pesticides
-Irrigation

(Bacenetti et al., 2015; Lehmann et al., 2020; Lovarelli et al, 2020;

Naudin et al., 2014; Noya et al., 2015; Zucali et al., 2018)

- Acidification (kg SO2-eq./yr) - (Bacenetti et al., 2015; Lehmann et al., 2020; Lovarelli et al, 2020; Naudin et al., 2014; Noya et al., 2015; Zucali et al., 2018)

- Eutrophication (kg PO4-eq./yr) - (Bacenetti et al., 2015; Lehmann et al., 2020; Lovarelli et al, 2020; Naudin et al., 2014; Noya et al., 2015;
Eurostat

Eurostat

Web of Science and Scopus

Web of Science and Scopus

Web of Science and Scopus 
Zucali et al., 2018)

- Energetic Efficiency (MJ/MJ) - (Bacenetti et al., 2015; Lehmann et al., 2020; Lovarelli et al, 2020; Naudin et al., 2014; Noya et al., 2015;

Zucali et al., 2018)

Web of Science and Scopus

District

(LCA\Quantitative environmental evaluation):

Agri-environmental:

- GWP (kg CO2-eq./yr):

Web of Science and Scopus

-Human

-Livestock 


\section{-Tillage \\ -Fertilizers \\ -Pesticides \\ -Irrigation}

(Bacenetti et al., 2015; Lehmann

et al., 2020; Lovarelli et al, 2020;

Naudin et al., 2014; Noya et al.,

2015; Zucali et al., 2018)

- Acidification (kg SO2-eq./yr) - (Bacenetti et al., 2015; Lehmann et al., 2020; Lovarelli et al, 2020; Naudin et al., 2014; Noya et al., 2015;

Web of Science and Scopus

Zucali et al., 2018)

- Eutrophication (kg PO4-eq./yr) - (Bacenetti et al., 2015; Lehmann et al., 2020; Lovarelli et al, 2020; Naudin et al., 2014; Noya et al., 2015;

Web of Science and Scopus Zucali et al., 2018)

- Energetic Efficiency (MJ/MJ) - (Bacenetti et al., 2015; Lehmann et al.,

Web of Science and Scopus 2020; Lovarelli et al, 2020; Naudin et al., 2014; Noya et al., 2015;

Zucali et al., 2018)

Agri-environmental:

Web of Science and Scopus

- GWP (kg CO2-eq./yr):

-Human

-Livestock

-Tillage

-Fertilizers

-Pesticides 


\section{-Irrigation}

(Bacenetti et al., 2015; Lehmann et al., 2020; Lovarelli et al, 2020;

Naudin et al., 2014; Noya et al., 2015; Zucali et al., 2018)

- Acidification (kg SO2-eq./yr) - (Bacenetti et al., 2015; Lehmann et al.,

Web of Science and Scopus

2020; Lovarelli et al, 2020; Naudin et al., 2014; Noya et al., 2015;

Zucali et al., 2018)

- Eutrophication (kg PO4-eq./yr) - (Bacenetti et al., 2015; Lehmann et

Web of Science and Scopus

al., 2020; Lovarelli et al, 2020; Naudin et al., 2014; Noya et al., 2015;

Zucali et al., 2018)

- Energetic Efficiency (MJ/MJ) - (Bacenetti et al., 2015; Lehmann et al.,

Web of Science and Scopus

2020; Lovarelli et al, 2020; Naudin et al., 2014; Noya et al., 2015;

Zucali et al., 2018)

Annex II: crops-related environmental indicators referred to Northern Italy context.

\begin{tabular}{|c|c|c|c|c|c|c|c|c|c|c|}
\hline $\begin{array}{c}\text { Crops } \\
\text { Category }\end{array}$ & Paper & $\begin{array}{l}\text { Climate } \\
\text { Change } \\
\text { (CC, } \\
\text { express } \\
\text { ed as kg } \\
\text { CO } 2 \\
\text { equival } \\
\text { ents } \\
\text { ha^-1) }\end{array}$ & $\begin{array}{l}\text { Climate } \\
\text { Change } \\
(\mathrm{CC}, \\
\text { express } \\
\text { ed as kg } \\
\mathrm{CO} 2 \\
\text { eq. } \\
\left.\mathrm{Mg}^{\wedge}-1\right)\end{array}$ & $\begin{array}{l}\text { Particulate } \\
\text { Matter } \\
\text { Formation } \\
\qquad \text { (PM, } \\
\text { expressed as } \\
\text { kg PM2.5 } \\
\text { eq. Mg^-1) }\end{array}$ & $\begin{array}{l}\text { Pesticide } \\
\text { and } \\
\text { herbicide } \\
\text { use (kg } \\
\text { ha^-1) }^{\wedge}\end{array}$ & $\begin{array}{l}\text { Human } \\
\text { Toxicity } \\
\text { (kg 1,4- } \\
\text { DB eq. } \\
\mathrm{Mg}^{\wedge}-1 \\
\text { DM) }\end{array}$ & $\begin{array}{l}\text { Photochemical } \\
\text { Ozone } \\
\text { Formation } \\
\text { (POF, } \\
\text { expressed as kg } \\
\text { NMVOC eq. } \\
\left.\mathrm{Mg}^{\wedge}-1 \mathrm{DM}\right)\end{array}$ & $\begin{array}{l}\text { Terrestrial } \\
\text { ecotoxicity } \\
\text { (1.4- } \\
\text { dichlorobenz } \\
\text { ene eq. kg } \\
\left.\mathrm{Mg}^{\wedge}-1\right)\end{array}$ & $\begin{array}{l}\text { Acidification } \\
\text { (kg SO } 2 \text { eq. } \\
\left.\mathrm{Mg}^{\wedge}-1\right)\end{array}$ & $\begin{array}{l}\text { Eutrophication } \\
\qquad \begin{array}{l}\text { (kg PO } 4 \text { eq. } \\
\left.\mathrm{Mg}^{\wedge}-1\right)\end{array}\end{array}$ \\
\hline Maize & $\begin{array}{l}\text { Bacen } \\
\text { etti et }\end{array}$ & $\begin{array}{c}1,929.0 \\
0\end{array}$ & 177.00 & & 6.00 & 17.33 & 0.01 & 0.06 & 8.25 & 4.38 \\
\hline
\end{tabular}




\begin{tabular}{|c|c|c|c|c|c|c|c|c|c|c|}
\hline $\begin{array}{l}\text { Green } \\
\text { maize }\end{array}$ & $\begin{array}{l}\text { Zucali } \\
\text { et al., } \\
2018\end{array}$ & $\begin{array}{c}2,528.0 \\
0\end{array}$ & 131.00 & & 3.00 & 16.63 & 0.01 & 0.04 & 4.75 & 2.46 \\
\hline $\begin{array}{l}\text { Green } \\
\text { maize }\end{array}$ & $\begin{array}{l}\text { Noya } \\
\text { et al, } \\
2015\end{array}$ & & 631.00 & & 6.00 & & 1.30 & 0.08 & 7.50 & \\
\hline $\begin{array}{l}\text { Rotation } \\
\text { Maize } \\
\text { and } \\
\text { RyeGrass }\end{array}$ & $\begin{array}{l}\text { Zucali } \\
\text { et al., } \\
2018\end{array}$ & $\begin{array}{l}3409- \\
3773\end{array}$ & 142.00 & & & $\begin{array}{l}29.87- \\
35.93\end{array}$ & $0.02-0.01$ & $0.08-0.06$ & $8.3-4.80$ & $3.77-1.96$ \\
\hline Triticale & $\begin{array}{l}\text { Noya } \\
\text { et al., } \\
2018\end{array}$ & & $738-445$ & & & $37-22$ & $1.02-0.61$ & $0.22-0.13$ & 26.00 & \\
\hline Wheat & $\begin{array}{l}\text { Noya } \\
\text { et al, } \\
2015\end{array}$ & & 498.49 & & 5.00 & 27.90 & 0.63 & 0.02 & 3.30 & \\
\hline Barley & $\begin{array}{l}\text { Lovare } \\
\text { lli et } \\
\text { al., } \\
2020\end{array}$ & & 184.89 & 0.14 & 0.59 & & 1.02 & & & \\
\hline Barley & $\begin{array}{l}\text { Noya } \\
\text { et al., }\end{array}$ & & 743.00 & & & 38.00 & 0.91 & 0.07 & 22.00 & \\
\hline
\end{tabular}




\begin{tabular}{|c|c|c|c|c|c|c|c|c|c|c|}
\hline & 2018 & & & & & & & & & \\
\hline Rye & $\begin{array}{l}\text { Noya } \\
\text { et al., } \\
2018\end{array}$ & & $695-571$ & & 6.06 & $27-23$ & & $0.19-0.16$ & $23-19$ & \\
\hline Triticale & $\begin{array}{l}\text { Noya } \\
\text { et al, } \\
2015\end{array}$ & & 492.18 & & 5.00 & 26.04 & 0.61 & 0.02 & 3.15 & \\
\hline Rice & $\begin{array}{c}\text { Bacen } \\
\text { etti et } \\
\text { al., } \\
2020\end{array}$ & & $\begin{array}{l}937.30- \\
832.70\end{array}$ & $0.44-0.38$ & & & $2.13-1.86$ & & & \\
\hline Pulses & $\begin{array}{l}\text { Forleo } \\
\text { et al., } \\
2018\end{array}$ & & 526.00 & & $6.02-0.68$ & 44.70 & $0.48-0.03$ & 0.32 & $14.97-4.03$ & $5.26-2.08$ \\
\hline Pulses & $\begin{array}{c}\text { Forleo } \\
\text { et al., } \\
2018\end{array}$ & & 307.00 & & $6.12-1.07$ & 72.81 & $0.39-0.06$ & 0.36 & $33.21-2.94$ & 1.48 \\
\hline $\begin{array}{l}\text { Other } \\
\text { Arable } \\
\text { Crops }\end{array}$ & $\begin{array}{c}\text { Manfr } \\
\text { edi et } \\
\text { al., } \\
2014\end{array}$ & & 258.57 & & & & 0.01 & & 0.50 & 1.97 \\
\hline Alfa Alfa & $\begin{array}{l}\text { Zucali } \\
\text { et al., } \\
2018\end{array}$ & 683.00 & 58.50 & & & 17.33 & 0.01 & 0.07 & 1.97 & 0.54 \\
\hline
\end{tabular}




\begin{tabular}{|c|c|c|c|c|c|c|c|c|c|c|}
\hline Alfa Alfa & $\begin{array}{c}\text { Bacen } \\
\text { etti et } \\
\text { al., } \\
2018\end{array}$ & & 84.54 & 0.07 & 2.00 & & 0.79 & & & \\
\hline $\begin{array}{l}\text { Horticultu } \\
\text { re }\end{array}$ & $\begin{array}{c}\text { Valian } \\
\text { te et } \\
\text { al., } \\
2019\end{array}$ & & 212.00 & 0.11 & & & 0.58 & & & \\
\hline $\begin{array}{c}\text { Permanen } \\
\mathrm{t} \\
\text { Grassland }\end{array}$ & $\begin{array}{l}\text { Zucali } \\
\text { et al., } \\
2018\end{array}$ & $\begin{array}{c}1,224.0 \\
0\end{array}$ & 129.00 & 0.00 & & 33.04 & 0.01 & 0.04 & 8.88 & 2.18 \\
\hline $\begin{array}{c}\text { Permanen } \\
\text { t Crops }\end{array}$ & $\begin{array}{c}\text { Lovare } \\
\text { lli et } \\
\text { al., } \\
2018\end{array}$ & & $\begin{array}{l}67.28- \\
63.24\end{array}$ & & & 7.9-7.10 & $0.4-0.32$ & & $1.54-1.51$ & \\
\hline
\end{tabular}

